La

Révolution

française

\section{La Révolution française}

Cahiers de l'Institut d'histoire de la Révolution française

22 | 2022

L'étranger en révolution(s)

\title{
A racist revolutionary: the literary career of Jean- François Dubroca as a propagandist of the French Consulate, $1800-1804$
}

Antonio de Francesco

\section{(2) OpenEdition}

Journals

Édition électronique

URL : https://journals.openedition.org/Irf/6347

DOI : $10.4000 /$ Irf.6347

ISSN : 2105-2557

Éditeur

IHMC - Institut d'histoire moderne et contemporaine (UMR 8066)

Référence électronique

Antonio de Francesco, «A racist revolutionary: the literary career of Jean-François Dubroca as a propagandist of the French Consulate, 1800-1804 », La Révolution française [En ligne], 22 | 2022, mis en ligne le 20 janvier 2022, consulté le 23 janvier 2022. URL : http://journals.openedition.org//rf/6347 ; DOl : https://doi.org/10.4000/Irf.6347

Ce document a été généré automatiquement le 23 janvier 2022.

(c) La Révolution française 


\title{
A racist revolutionary: the literary career of Jean-François Dubroca as a propagandist of the French Consulate, $1800-1804$
}

\author{
Antonio de Francesco
}

\section{Bonaparte's Atlantic ambitions}

1 Washington died unaware that he had a political heir on the other side of the Atlantic Ocean. However, Bonaparte, who had just taken power in France, swiftly claimed Washington's political legacy ${ }^{1}$ and looked to America as the theatre for his decisive move against England. He wanted to re-establish a good relationship with the United States, revitalise the island of Saint-Domingue-the wealth of which was destroyed by the slave revolt in 1791-and aimed at recouping Louisiana (and potentially Florida) from Spain in order to support the prosperous Caribbean colonies.

He knew exactly what he wanted. He deemed the Directory's policy to be wrong, aiming as it did to equalise all the French territories, in both Europe and America, to the institutional structure of metropolitan France. ${ }^{2}$ In his view, it was necessary to reestablish clear hierarchies. France was to be placed at the centre and equipped with a constitution favouring executive power. In Europe, affiliated political entities were no longer to be called 'sister republics' but rather 'satellite states', for which he envisioned a constitution different from that of France. In America, by contrast, overseas departments were to go back to their original state of 'colonies' to support the homeland's financial system. The Year VIII Constitution, the founding act of the new consular regime, made this political viewpoint quite clear, specifying that the colonies would be regulated by special legislation, which would give formal value to their distinctness while essentially ratifying their subordination. 
Once again victorious in Italy, Bonaparte started to give shape to his project. In October 1800 , he drew up an agreement with the United States, without mentioning that in the meantime Spain had returned Louisiana to him; in February 1801, he signed the Treaty of Lunéville with Austria and forced Britain to reach an agreement. Towards the end of the year, when peace negotiations were making a good deal of headway, he gave his brother-in-law, General Leclerc, command of an expedition to Saint-Domingue to overthrow Toussaint Louverture, the black governor whose freedom of action went against the reaffirmed subordination of the American colonies to the motherland. The apex of the First Consul's good fortune in the Americas occurred in Spring 1802: in March, he signed the Treaty of Amiens with Britain, which returned Martinique, Tobago and Saint Lucia to France; a few weeks afterwards, Louverture was captured and plans were laid to regain control of Louisiana. In this way, Bonaparte was sure he could overturn power relations with Britain in the Western hemisphere, dominate the goods trade all across the New World and crush Britain's presence in the Caribbean region. ${ }^{3}$

The unexpected event that ruined all his plans was the decision of 30 Floréal, Year X $\left(20^{\text {th }}\right.$ May 1802) to maintain slavery in the colonies that had just been returned to France by England. The move implied that the abolition of slavery, voted on 16 Pluviôse, Year II ( $6^{\text {th }}$ February 1794 ) by the Convention in the aftermath of the events in Saint-Domingue, was not going to happen after all. This suspicion was soon confirmed when another French contingent arrived in Guadeloupe and immediately set to work to reinstate slavery. In nearby Saint-Domingue, this move stirred harsh protests by some black and mixed-race generals, who nevertheless had helped in the capture of Louverture. Fearing that the events in Guadeloupe were a foretaste of what could happen to them as well, they rebelled against the French contingent. This marked the beginning of a war that culminated with the defeat of Bonaparte's troops. In January 1804, the new state of Haiti came into being. General Jean-Jacques Dessalines was accused of slaughtering those whites who had not managed to escape along with the French soldiers to keep Haiti's population wholly black.

Simultaneously, hostilities with Britain had resumed in May 1803, and Bonaparte, no longer needing Louisiana as an entrepot for Saint-Domingue, made provisions for selling it to the United States. The French Empire had already lost some of its possessions in the Americas, and, in 1805, the ruinous naval battle of Trafalgar shattered France's dreams of expansion in the New World.

6 That does not mean, however, that Bonaparte had not believed in the endeavour or that he had not contemplated a day of reckoning to avenge defeat in the Seven Years' War by going back to the very place where France's misfortunes had originated. ${ }^{4}$ His American plans had not been without their weaknesses, however-above all the fact that the United States feared France's presence in Louisiana-, but they failed in the end because Bonaparte wanted to adopt the same techniques in the New World that he had so successfully employed on the other side of the Atlantic.

7 In France, the pacification of Vendée and compromise with the Catholic Church had demonstrated the validity of his ralliement policy, namely, his resolution to reach out to all those who, once opponents of the Revolution, were now willing to support the new order. It was a strategy that would also prove to be successful in French-dominated European areas: the First Consul became President of the Italian Republic, issued the 
Act of Mediation between the Helvetian cantons and was able to control the elections in the Batavian Republic.

8 From his point of view, there was no apparent reason why he could not operate similarly in the Americas, and the first testing ground was the decision to maintain slavery in the colonies that had been newly handed back by Britain. This is considered -rightly-as a tragic step backwards on the path towards civil rights; Bonaparte, nevertheless, reckoned it to be an advantageous move, given that the landowners in those colonies wanted to preserve the slavery that the British troops had allowed them to practice..$^{5}$ It was, in other words, unconscionable pragmatism that prompted the First Consul not to alter the social structure of Martinique, Tobago or Saint Lucia in order not to lose the planters' support, which was crucial to the development of a large-scale commercial policy in the Americas. ${ }^{6}$ Previously though, with regard to Saint-Domingue, Bonaparte had taken the opposite approach and had disappointed all those expecting the abolition of slavery to be abandoned. On the island, where the slave rebellion had brought about that decision, Louverture was the dominant figure, and Bonaparte, for the very same reasons that forced him elsewhere to be a supporter of slavery, tried at first to win him over to his side. Their exchange of letters suggests that Bonaparte believed that he could place his faith in Louverture. This explains why he reacted so vigorously when the governor, rather than obey, and without even notifying the First Consul, nonchalantly borrowed certain words from the Year VIII Constitution regarding the characteristics of the colonies in order to endow the island with its own specific constitution. ${ }^{7}$

9 In any case, in the colonial world, too, the First Consul proposed his policy of ralliement again, believing that although Martinique had remained untouched by revolutionary contagion and Saint-Domingue had obtained the abolition of slavery, this would not prevent the two systems from coexisting. In retrospect, it would be easy to blame Bonaparte for having underestimated the revolutionary impact of the 1794 decree and for not taking into account the black population's desire for freedom. At the time though, French public opinion-the only one to which the First Consul was susceptible -called for pacification without restoration. It was a demand that implied a wish neither to return to the circumstances caused by the revolution, nor to convert those who had remained immune from it. The issue of slavery was not contemplated by this status quo policy and there was, therefore, no space for the aspirations of those who were still denied liberty, even while it was not ruled out that those who had gained their freedom might be allowed to preserve it. Although many claim that Bonaparte had planned all along on re-establishing slavery, the example of the United States proved that, depending on the individual local context, freedom and slavery could coexist, and this was probably the path that Bonaparte wanted to follow in order for his voice to be heard in the New World.

10 This American prospect has remained a rather obscure affair for a long time, as Bonaparte, by then Napoleon I, Emperor of the French, willingly consigned his plans for a trans-Atlantic empire to oblivion in order to stifle any news regarding the defeats he had suffered in the New World. ${ }^{8}$ None of this alters the fact that his plan got off to a good start, or that, throughout all the years of the Consulate, Bonaparte insisted that an American version of his political perspective was required. The problem lay with the different expectations aroused in French society. Conservative circles, which included the colonists in Saint-Domingue, called for an end to the Directory's policy in favour of 
black and mixed-race people and for the reinstatement of slavery. For those who believed in Bonaparte's identity as a Republican, the Americas were the place where any balance of power favourable to England should be overturned and a new colonial society inspired by France's civilising tenets should be founded. These were two different lines of thought that were bound to clash, particularly with regard to proslavery Britain, but Bonaparte-indifferent to the socio-cultural profile of the new American empire-allowed them to coexist even within his own government. He was convinced that both lines strengthened his American strategy-a strategy he wanted to guide public opinion towards through incessant propaganda.

11 Something of this sort is suggested by his arrêté of 27 Nivôse, Year VIII (17 $7^{\text {th }}$ January 1800), through which he forced many newspapers to shut down, while allowing brochures and pamphlets to circulate and promoting the opening of new bookshops. ${ }^{9}$ In the years of the Consulate, these became tools for legitimising his political ideas, with Bonaparte availing himself of an array of intellectuals, chosen from amongst those savants who had grown in number during the years of the Revolution ${ }^{10}$ and who were more than willing to praise the new order as long as they were on the government payroll. ${ }^{11}$ In all of this, there was nothing new since, during the Seven Years War, many propagandists were already supported by the ministry and given access to government papers. ${ }^{12}$

The bookseller Dubroca was no exception. At the beginning of 1801 , he opened his workshop at 1760 rue Thionville and he launched a business mostly aimed at printing and selling his own writings. Dubroca, who was active throughout the whole Napoleonic era, was the eclectic writer and author of several books on the most relevant topics of the time, often composed by ransacking the works of other authors. ${ }^{13}$ Nowadays, however, he is known for his biographies of Toussaint Louverture and JeanJacques Dessalines, two portraits denigrating the leaders of the Saint-Domingue uprising. Because of the abundance of racist motifs, the two works have garnered some attention in recent years, specifically in post-colonial studies. ${ }^{14}$

However, Dubroca had a vibrant revolutionary past, concealed by his most famous works, but which is worth remembering because it suggests a different interpretation of Bonaparte's policy towards the American colonies. Initially, Dubroca's works interpreted the Consulate's actions as a great civilising endeavour that would give rise to a perfectly turned-out Republican citizenry. The biography of Toussaint Louverture (1802), for example, exposed the supposed hypocrisy of the black governor, who was accused to have secretly negotiated the colony's independence with England, but also praised the civilising nature of slavery's abolition. This outlook, which maintained a link with the Directory's political culture and insisted on the Republican identity of the Consulate, did not however stand the test of the American events, and Dubroca, following Haiti's independence, claimed that the universalist ideal of the Enlightenment was exhausted. This was evident in his biography of Jean-Jacques Dessalines (1804), abundant with motifs of black inferiority and descriptions of the black population's barbarity-his observations, however, were once again instrumental in placing the blame on Britain, designating it as the real culprit behind the slave rebellion.

14 In this way, Dubroca's writings allow us to pinpoint the exact place and time when racism took a decisive leap forward, ${ }^{15}$ while also hinting, in this respect, at a motivating force that philosophical, literary and anthropological considerations often tend to 
disregard. He would lead us to believe that the birth of Haiti-a world turned upside down and lost, where barbarity had got the better of civilisation-was the outcome, to some extent predictable, for which Britain had been striving for so long. Bonaparte's France had been fighting a war of civilisation in the Americas not against the blacks, deemed capable only of violence as an end in itself, but rather against a fellow nationalthough one that was willing even to annihilate its own kind in order to satiate its hunger for supremacy. Dubroca's work thus allows us to understand that the conflict between the European empires in the Americas was not only military, but cultural. For this reason, if arms were crucial for the black rebels to triumph, the shared identity of the white adversaries ratified their exclusion from the context of civilisation. In other words, the Haitian plight in the $19^{\text {th }}$ century Americas ${ }^{16}$ was not the product of the joint hostility of the great world powers against an "unthinkable fact"-that is, an inconceivable (and therefore unacceptable) event that challenged their supremacy with its revolutionary model. ${ }^{17}$ Rather, above and beyond the concerns this revolution raised locally, ${ }^{18}$ the expectations encouraged among the slaves of the New World, ${ }^{19}$ and the dramatic collapse of French trade, ${ }^{20}$ the silence that followed the birth of $\mathrm{Haiti}^{21}$ was a reflection of the contemptuous observation that only armed conflict between the British, French and Spanish had brought about an outcome that was otherwise unrepeatable. Haiti was not born out of a revolution-a term that entailed a political profile denied to blacks-but rather out of a display of bestial violence fomented by certain whites in order to triumph in a conflict that was exclusively their own. This explains why the Saint-Domingue revolt and the birth of Haiti's black state-now considered a fundamental moment in the age of revolutions-were, for a long time, treated as one circumscribed, insignificant episode. ${ }^{22}$ The silence arose not from concern or bewilderment but rather out of an arrogance dictated by a cultural strength thought to be even more incontrovertible than military force.

\section{Dubroca... chi era costui?}

15 The question on Dubroca's identity is not easy to answer. From a political point of view he was one of the many girouettes present in revolutionary France: he was a priest and a patriot, he was defrocked and married, divorced and remarried, an advocate first of dechristianisation and then of theophilanthropy, an extremist and an anti-robespierrist, in two different moments also a royalist hailing the four dynasties present in millenarian French history, then again bonapartist, yet republican during the last adventure of the Hundred Days, before losing himself in the mists of the Restoration.

His real name was Jean-François, and not Louis, as library catalogues-following Querard's bibliography-inevitably certify. ${ }^{23} \mathrm{He}$ was born in Saint-Sever, a commune in the Landes department, on $16^{\text {th }}$ December 1757 , and was steered by his family towards priesthood. He was in Paris during the revolutionary years and renounced his vows after the fall of the monarchy. ${ }^{24}$ Having been close to the de-christianisation movement in Year II, after the Terror, he was among the leading proponents of theophilanthropy, a strange form of philosophical deism supported by the Directory in order to counteract Catholicism and, through Republican culture, promote a renewal of civic spirit. ${ }^{25}$ Grégoire, who knew him in those years, described him as the finest orator in the sect, ${ }^{26}$ and this particular skill helped him to join the Portique républicain, an ultra- 
democratic literary society established in 1799 , which was inspired by the values of reason and intended to promote authentically Republican ethics. ${ }^{27}$

The coup of 18 Brumaire soon silenced the movement, but it would be wrong to depict it as a den of incorrigible adversaries to the First Consul. Dubroca himself was among those who applauded the Corsican general, having admired Bonaparte since his campaign in Italy and seeing in his seizure of power the birth of a government robustly intent on supporting Republican political culture. After all, his decision to open a bookshop was in keeping with his plan to construct a new framework of popular ethics, and the texts that he began to publish followed two profoundly interlinked editorial directions. On the one hand, he specialised in publishing ethical and pedagogical works that would disseminate the principles of Republicanism; on the other, he kept a close eye on current political events, specifically in the overseas colonies, with a timeliness that would earn him the accusation by the British of being in the pay of the French government.

As we will see, this suspicion was justified; but Dubroca understood how important the colonial issue was for Bonaparte, and, with the example of the United States, saw the Americas as the new frontier for Republican ethics. Thus, during the Portique républicain session of $7^{\text {th }}$ March 1800, Dubroca delivered an inspired eulogy for Washington, clearly redolent with confident expectation towards Bonaparte, as though confirming the close connection between the two Republics. ${ }^{28}$ So, holding up the portrait of the American president here against the light, so to speak, the political traits of the First Consul can be traced. Washington is praised as being the embodiment of Republican virtue: he laid the foundations for American liberty, then, when it was established, had withdrawn into private life, only to return to the political arena when his homeland's freedom was newly endangered. He can be credited with having distinguished civil from military power and for sacrificing everything to the values of citizenship. In other words, his speech showed, through his unrelenting commitment to his endangered homeland, the fact that Dubroca faithfully expected Bonaparte to embrace Washington's example. ${ }^{29}$

The eulogy was printed by Nicolas Des Essarts, an anti-robespierrist editor and eclectic writer, who, during those same years, ${ }^{30}$ also reprinted a pamphlet penned by Dubroca against Britain, a piece that had already appeared in September $1798 .{ }^{31}$ Oddly enough, Des Essarts preceded Dubroca's work with another essay, published a few months earlier by the Member of Parliament Boulay de la Meurthe, on the English revolution of $1640 .^{32}$ The editor did not clarify his reasons for deciding to present the two works together. ${ }^{33}$ The journal Ami des Lois, however, had already explained those reasons in a review that had appeared the previous February. Boulay recalled how the spirit of faction was the cause of the English republic's fall, while Dubroca encouraged the French people not to make the same mistake. ${ }^{34}$ Any possible comparison between Cromwell and Bonaparte was, therefore, ruled out because-at the time of the reprinting-Boulay had just presented the Year VIII Constitution to the legislative body as the outcome of a Revolution that had eliminated factions and thus represented the general will of the people. ${ }^{35}$

It was on this terrain, therefore, that Des Essarts (and Dubroca) transplanted the comparison between the historical experiences of the two revolutions in order to make it possible to contrast one against the other. In France, the struggle against the Ancien Régime had led to freedom, whereas, on the other side of the English Channel, the experiment had soon failed, consigning the English people to the whims of despotic 
governments. In Dubroca's work, all this came about from the same arrogance with which London's executive branch had striven to sabotage the French Revolution.

It is no coincidence that in that punctilious j'accuse, a great deal of attention was paid to Pitt's aggressive handling of the situation in Saint-Domingue. In Dubroca's view, the debate on the slave trade encouraged within the Commons was a ploy designed to cause problems for the French public opinion. The Sociéte des Amis des Noirs endorsed those arguments and launched a campaign for abolishing slavery, which, in Saint-Domingue, had however exacerbated the conflict between the factions and had greatly favoured the uprising. Dubroca thus suggested that Pitt's manoeuvres instigated the wealthy planters's attempt to secede from France, as they had with the slaves who rebelled in 1791. In both cases, what mattered to Britain was the financial collapse of the French colony. ${ }^{36}$

In these considerations, an echo can be traced of the polemic Louis-Sébastien Mercier stirred up against the Amis des Noirs as confirmation of how Dubroca made Mercier's ideas a clear political and cultural point of reference. ${ }^{37}$ At any rate, in the first months of 1800 , re-publishing a text that was vigorously hostile towards Britain played into the hands of those who supported Bonaparte's decision to initiate a military operation in Saint-Domingue, and there was no doubt that Dubroca was in agreement with this. In fact, in July, at a Portique républicain gathering, he paid a heartfelt tribute to General Desaix, the unfortunate victor of the battle of Marengo, and on that occasion "the repeated names of Bonaparte, conqueror of Italy and peacemaker of the world, and the brave Desaix [...] filled all hearts with enthusiasm". ${ }^{38}$

In the following months, Dubroca was co-opted into the Parisian Sociétélibre des sciences, lettres et arts, where he tried to make a name for himself in the capital's cultural world, and where he met Grégoire. The latter wrote a commentary outlining Dubroca's reasons for leaving the theophilanthropist cult, a work resembling an overt subscription to Bonapartist policies. ${ }^{39}$ Shortly thereafter, Dubroca attempted to open a direct dialogue with the government: towards the end of 1800, he asked Member of Parliament Louis Rallier, a theophilanthropist who had supported the Brumaire coup, to put him in touch with Roger Ducos, vice-president of the Conservative Senate and a former provisional consul, in order to obtain a position at the Ministry of Education. His activism with the theophilanthropists, however, specifically worked against him and prompted the executive body, keen to establish an agreement with the pope, to politely decline his request..$^{40}$ In addition, the Portique républicain would soon shut down, being too left-leaning to survive the Consulate's ideological apparatus. At that stage, all that was left for Dubroca was to pursue a career in private teaching and to try to sell his own writings. ${ }^{41}$

Towards the end of 1801, when London's preliminary agreements leading to the Treaty of Amiens (1802) were made public, Dubroca launched his publishing business, starting with a biography of the First Consul. The text, obviously celebratory in tone, portrayed Bonaparte as the true representative of the revolutionary spirit and engineer of the victorious peace. ${ }^{42}$ The pamphlet, preceded by a speech that Dubroca had already published in 1797 specifically for the General's first Italian campaign, ${ }^{43}$ appeared in bookshops in the first days of $1802 .{ }^{44}$ However, its author, following the current political debate, was already writing about the Saint-Domingue expedition.

From the end of 1800 , police reports communicated that the capital was shaken by the news that Louverture had endowed the colony with a constitution in order to pave the 
way to independence. Rumors fed suspicions that Britain was manipulating events from behind the scenes and whipped up fears that the whites on the island were being exposed to black retaliation. ${ }^{45}$ This news, skilfully circulated by the police themselves, fomented the patriotic zeal of the population, who enthusiastically welcomed the departure of the French fleet for Saint-Domingue. Shortly after the troops landed on the island, however, rumour had it that they faced imminent destruction at the hands of the armed resistance being sent against them. ${ }^{46}$

Tension encouraged a general feeling of resentment towards Louverture and, during those same days around the end of March 1802, Dubroca put on the market a biography of the black governor portraying him as a traitor. ${ }^{47}$ The work was a sort of history of current events, starting with the slave rebellion in 1791 in order to explain Louverture's military and political rise, and ending in February 1802, when he ordered that the town of Cap be set on fire to impede the arrival of the French troops. Dubroca's aim was to reassure the public and to prove how the black governor was at that stage abandoned by everybody, even the British: while Pitt's government may have favoured his ascent, the Addington ministry was now acting in cooperation with the French. It is interesting to note how the author, who had previously thundered against Pitt's interference on the island, was now adapting to the new political scenario, expressing words of understanding with regard to Britain's previous actions ${ }^{48}$.

Shortly afterwards, the Treaty of Amiens and Louverture's capture seemed to support Dubroca's position and stimulated the circulation of his work, the sales of which eclipsed those by other authors who published on the same subject. ${ }^{49}$ In that same year, his book was translated into Swedish ${ }^{50}$ and twice into English. In the United States, the person in charge of the translation was Nicholas Herbemont, a Frenchman who had emigrated to South Carolina during the Terror and who highlighted the dangers slave owners were exposed to in that state. ${ }^{51}$ The English edition, however, enjoyed a far wider distribution, to the extent that it landed on the desk of John Adams, then President of the United States, who, in his copy, wrote that the text was 'an infamous calumny, on a great hero, a real patriot, and a good man'. ${ }^{52}$

As a matter of fact, the biography Vie de Toussaint Louverture represents pure political propaganda of a libellous kind, which corroborated the reasons that had motivated the First Consul to overthrow the governor. Unsurprisingly, Dubroca places Louverture's disloyalty front and centre, accusing him of wanting to separate the colony from France. The governor's hypocrisy revealed itself in his brutality and superstitious religiousness, through which he exercised his own unchallenged command. The slaves were wholly unprepared to stand up to a man of such ruthless determination and clearheaded intelligence-someone who had taught himself how to read and write in order to free himself from slavery. In his thirst for supremacy, Louverture had overcome the cultural barrier hindering the progress of his people, but this had not allowed him to free himself from the savagery that all blacks, victims of a backward and violent African society, were subject to. Dubrocas' words reflected the stereotypes regarding the African population that the centuries of Enlightenment, even in attitudes more sympathetic towards the drama of slavery, had managed to magnify. Blacks were victims of a vicious ignorance, the direct consequence of a state of barbarity, which prevented them from progressing and which placed them in a subordinate position in relation to whites. Louverture, regardless of his powerful position within the colony, was no exception: at the end of the day, he remained a man of violence whose 
intelligence, expressed only through sheer ferocity, demonstrated the cultural backwardness of the people to whom he belonged.

However, Dubroca was keen to draw lessons from the Enlightenment and from those who had believed in the civilisation of the blacks, remaining staunch in his belief that the revolution could guide them on the path to progress. In describing the SaintDomingue events, he stayed true to a spirit that was informed by his revolutionary past, and which rested on the juxtaposition between the new Republican morality and the antiquated barbarity of the Ancien Régime. The backwardness of the blacks was particularly useful for his attempts to differentiate Republican France-which had wanted the end of slavery and had called on all citizens, de quelque couleur qu'ils fussent, 'of whatever colour they were', to take part in the colony's government-from the leaders of the revolt, who had remained slaves, given that the darkness of ignorance made them instruments in the hands of the reactionaries. During the years of his political rise, Louverture had first been guided by monarchists and had surrounded himself with priests, with his extremely religious zealotry pushing him to perpetrate a number of massacres. Afterwards, he moved on to serve the king of Spain, where he, a former slave, could sport the trappings of nobility..$^{53}$

The slave war in Saint-Domingue thus resolved itself in defence of church and monarchy and appeared to represent, as Dubroca explicitly comments, an echo of the war in Vendée. All the enemies of the Revolution, foreign powers included, had steered Louverture's actions until he, acknowledging the power of Republican institutions, saw fit once again to side with France. All of this, however, was just a ploy to free himself from Spanish tutelage and gain more power. Proof of this was his expulsion of Commissioner Sonthonax, despite the latter's support for the abolition of slavery, accusing him before the Directory of wanting independence for the colony. He then went on to discredit Hédouville, Sonthonax's successor, by hinting that he wanted to re-establish slavery in the colony. Finally, he rid himself violently of the mixed-race General Rigaud, who was forced to take shelter in France. Falling prey to megalomania and counting on the Directory's weakness, Louverture was about to declare independence and ally himself with the English, had it not been for Bonaparte's ascent to power and the declaration of a special regime for the colonies. This prompted him to come up with a constitution of his own, thereby cutting all ties with the motherland. So, Saint-Domingue declared its independence and Dubroca's thoughts on the matter were blunt: the First Consul was right to organise an expedition to restore order on the island to return it to France.

In the context of a book that equated the Saint-Domingue uprising with that of Vendée, ${ }^{54}$ there was not much space to linger on racial prejudice. While Dubroca no fewer than four times reiterated that Louverture was an African-associating that term with the fact that he was couvert de sang, féroce, forcené, farouche, 'covered in blood, fierce, mad, savage ${ }^{55}$-these origins never led him to dispute the abolition of slavery. Certainly, the slaves received their fair share of attacks in the text, portrayed as credulous, primitive and savage-but it is precisely their serious deficiencies that demonstrated the greatness of France's legislative endeavour, which had nonetheless freed them from their chains. The 1794 decree was in fact presented as proof of the indissoluble relationship between the motherland and the black population: the latter, owing everything to France, would certainly have opposed secession and distanced themselves from Louverture. 

is confirmed by the absence of accusations against the Sociéte des Amis des Noirs. Some passages also show that the author was an avid reader of the Moniteur as well as familiar with ministerial circles and that he had access to the reports dispatched by the French agents François-Marie Kerversau and Antoine Chanlatte, who tried in vain to oppose Louverture before arriving in Paris in September $1801 .{ }^{56}$ These were, therefore, his sources for a literary piece that had evidently been commissioned by the government. It is worth emphasising that, while the Navy Minister, Denis Decrès, was a staunch supporter of slavery, the two above-mentioned agents were good patriots, who accused the black governor of wanting independence; but who did not, for this reason, want to challenge the abolition of slavery. ${ }^{57}$ This was also, after all, Dubroca's line of thought as he gave voice to those who only wanted to re-establish the rights of metropolitan France, eliminating from the picture a politician who was fanning the flames of secession.

It follows that Dubroca praised the legislative endeavours of the National Convention and distanced himself from the Directory, which, in contrast, had lent itself to Louverture's slanders. Dubroca's support for the Consulate came, in other words, from out of the blue-something he would be criticised for at a later stage ${ }^{58}-$, because he insisted on the cultural and political value of the abolition of slavery, which he traced back to the actions of the First Consul himself. This is illustrated in the text by his stance in favour of Sonthonax and opposing Member of Parliament Vaublanc, who championed the colonists' demand for reinstating slavery. On many other points, Dubroca showed firm support for the moralising value of France's presence in the Caribbean. He praised commissioners Hédouville and Roume, depicting them as victims of Louverture's deceitfulness, while denouncing as true traitors Vincent, Hédouville's accuser in France, and Henri Pascal, who drew up the Saint-Domingue constitution. It is in this context that we need to interpret his statement-thereafter repeated in each subsequent biography of Louverture-that the black governor was a devoted reader of Raynal and had wholeheartedly accepted the comparison with Spartacus made by the French General Laveaux in a moment of enthusiasm bordering on weakness. ${ }^{59}$ In truth, Dubroca gave little weight to that particular episode, which interested him mainly in that it allowed him to criticise the fanaticism of certain French figures, who had renounced the morality of Republican institutions in order to pander to Louverture's ambitions. The latter, in this case, was touched only indirectly by the comparison, since the true target of Dubroca's censure was Laveaux himself, who, not by chance, the First Consul had just ordered to be arrested because of his sympathies with neo-Jacobin circles in $1799 .{ }^{60}$

Dubroca's pamphlet reflected, therefore, a specific political outlook within the executive: it was necessary not only to remove the counter-revolutionary Louverture from the scene but also to reaffirm the civilising mission of the expedition sent by Bonaparte, which revived, and brought to completion, the best aspects of the Revolution. 


\section{From Louverture to Dessalines}

As the return of the colony was taken for granted at the time, editors were competing to publish titles dealing with the topic. Observations on the matter by Louis XVI's minister Vergennes made a posthumous appearance, ${ }^{63}$ but, above all, there came out a first account by Louis-Narcisse Baudry des Lozières, ${ }^{64}$ who had given voice to all those who had settled in Louisiana after escaping from Saint-Domingue following the black rebellion. There were favourable conditions for the arrival of the slaves in the colony and Baudry des Lozières, a close collaborator of Decrès at the ministry, had clear ideas about how to proceed: slaves had to be imported to Louisiana; supporters of the abolition of slavery should not be allowed in; and it should be forbidden for black people, even individually, to achieve liberation. All of this could be accomplished with the support of the Native Americans, who felt superior to black people and would never join forces with them. It was important therefore, with regard to the "savages" who rebuffed fugitive slaves and contributed to keeping peace in the colony, to maintain a good relationship with them by purchasing their land instead of conquering it, and praying that, eventually, the Christian religion would work a miracle and civilise them. ${ }^{65}$ When Baudry des Lozières wrote these words, another of his works supporting slavery, Les égarements du nigrophilisme, was already in circulation. His activism gives a clear indication of what Bonaparte's American empire would have looked like had the French managed to quash the resistance encountered in Saint-Domingue. ${ }^{66}$

Dubroca, however, took the opposite direction, hoping to pique the reader's attention by outlining the history of the French presence in Louisiana since the late $17^{\text {th }}$ century. Relying on the many accounts available to him, he then moved on to provide a detailed description of the natives, present an evaluation of commercial activities and outline a summary of the economic prospects opening up since the region's return to France. Nothing was said about either the blacks or the organisation of slave-based labour. The only mention of Saint-Domingue, in fact, suggested that Louisiana was, in reality, the most suitable region for (re)building the French Empire in the Americas. ${ }^{67}$ Essentially, the book was in opposition to circles favourable to slavery and interpreted Bonaparte's policies in the New World as a call to action to all that was best and most dynamic in French society to make a forthright commitment to colonisation. In Dubroca's view, the Americas were too important a region to be left in the hands of bandits, misfits, women of ill repute and slaves. What was needed, instead, was a direct drive by the government to encourage emigration, so that the colony would experience rapid development-in a cultural sense, too. A clear appeal to the French genius emerged, in order for it to establish in the New World those refined forms of civilisation for which it was renowned in Europe. Not coincidentally, the reference point was, once again, Mercier, who, in the latest version of his work An 2440, supported the reasons for a civilising presence in Northern America, following precisely the same rationale. ${ }^{68}$ In this way, Dubroca reaffirmed the Illuminist model of civilising power, which had, for quite some time, been backing colonialist discourse and, albeit in conflict with the jeremiads of anti-abolitionist circles, legitimising the robust return of French forces to the New World. For this reason, the text was regarded favorably by the executive and 
was considered a useful tool in assisting the preparations of the French fleet to set out for Louisiana. Once again, Dubroca's words echoed Bonaparte's political ideas:

At a time when the political services of the government are announcing the interest that inspires the recent possession of Louisiana; at a time when all eyes are open to the advantages of this colony, I believe that I am undertaking a useful thing, by gathering under one point of view all the authentic information which exists on this region of America. ${ }^{69}$ gaze elsewhere-also because the Treaty of Amiens was beginning to look like only a temporary truce in a conflict that was bound to reignite. Dubroca's bookstore, in the meantime, had started specialising in educational material, adapting certain works from the French literary tradition to the new political landscape. Thus, between 1802 and 1803, he published some texts of sacred oratory by Fénelon and Gaichiés that would help religious ministers in their evangelical mission, and offered a condensed version of Bossuet's Histoire universelle, with clear references to the providential unity of the state. He reprinted a treatise by Jean-Baptiste de la Salle on the ethical rules to be taught to children and distributed a conspectus on the art of warfare-with copious additions on the revolutionary era-which he dedicated to General Berthier. He also published a geography handbook, which highlighted France's new administrative dimensions..$^{70}$ Alongside these ventures, all of them with evident government support, Dubroca continued to place an emphasis on oratorical discipline, issuing a treatise on the art of public speaking that would go through multiple editions and that would even allow him to open an acting school on his bookshop premises. ${ }^{71}$

The resumption of hostilities with England forced him to speak out once more regarding international events. His writings on Louisiana were useless at that point, given that, during those months, Bonaparte had given up ownership of the colony, to the great benefit of the United States. Meanwhile, yellow fever and Dessalines' insurrection were creating a dramatic situation in Saint-Domingue. All that could be done was to once more point the finger of blame at Pitt, reprinting, this time on its own, the booklet from 1798 attacking Britain. ${ }^{72}$ The new edition came out in the summer of 1803 and was reflective of the current climate, ${ }^{73}$ joining the chorus of detractors against Great Britain, ${ }^{74}$ where, as already seen, Dubroca claimed a frontline position. His writing, as a typographic notice highlighted, was patriotic in sentiment:

This work [is] suitable for revealing the Machiavellianism of the British Ministry and to arouse the indignation of the French against its odious manoeuvres and to further fuel the patriotic zeal with which they support the vigorous measures taken by the French government and its leader to avenge the heinous violation of the most solemn and recent treaty. ${ }^{75}$

In fact, in this new edition, the tone became more heated, lacking as it did any praise for the English population, probably now considered to be more of a partner to, rather than simply a victim of, the government's policies. Furthermore, the original work was rewritten in order to make room for the events from Brumaire leading up to the severance of the Treaty of Amiens. In this regard, Dubroca's interpretation of the events in Saint-Domingue also underwent alteration, as he pinpointed the process of British interference in three specific moments: 1789 , when Pitt tried to encourage the secession of the colonists; 1791, when he fomented the slave revolt; and Year VI, when Commissioner Hédouville, who resisted the English, was removed from the island. ${ }^{76}$ 
Once again, the text was in line with Bonaparte's plans: The First Consul feared that the breakdown of the Treaty of Amiens was a sign that Saint-Domingue could no longer be defended and the only way forward therefore was to bolster patriotism and denounce British barbarity. The stakes of the challenge had to be raised-or not, as it turned out: first, the decision to organise an encampment in Boulogne to prepare for the invasion of Britain, and then the birth of the Empire-although Saint-Domingue was lostguaranteed a total war that would eventually (in theory at least) make it possible for the French to return to the island.

As usual, Dubroca took all this into consideration and made haste to publish other texts. First, the Constitutions of the Empire, together with a historical outline of the Consulate and another edition of a biography of Bonaparte already published in 1802. ${ }^{77}$ Then, towards the end of 1804, he issued a biography of Jean-Jacques Dessalines, who, only a few weeks earlier, had once more challenged Bonaparte by proclaiming himself the emperor of Haiti. ${ }^{78}$

was, in fact, a continuation of the book previously devoted to Toussaint Louverture, from which he borrowed entire passages in order to show how one man went on committing the crimes of the other. On this occasion, however, the underlying thread was the denunciation of Great Britain, accused from the foreword of having encouraged the slave revolt and condoned Dessalines' violent actions. The latter was portrayed as a cunning, tenacious and bloodthirsty criminal, who, illiterate and primitive, was a mere puppet in the hands of the English. In other words, the gruesome scenes inundating the text were to be a reminder that the savagery of the black revolt was only one facet of the violence that British politics propagated. All of this explains why the book was greeted with silence on the other side of the Channel, while it enjoyed widespread appreciation in those countries that stood with France in their hostility towards Great Britain. Within just a few months, the text was translated into German-also within the historical-literary journal Minerva-and into Flemish and Spanish ${ }^{79}$ including an 1806 edition printed in Mexico which was supplied with images of Dessalines' massacres. ${ }^{80}$

This latter version, however, calls for a small clarification, as the promoter of the venture, Juan Lopez Cancelada, editor of Gaceta de México and representative of New Spain's conservative circles, wrote a short introduction in which he admonished that the tragedy in Saint-Domingue should be interpreted as a warning to reject 1789's revolutionary paradigm. His intention was to rally all the whites against the threat that black and native peoples might pose to them; most of all, however, he cautioned readers with regard to all the talk of liberty that the British liked to promulgate in order to undermine Spain's credibility. ${ }^{81}$ Cancelada hit the mark here, given that Dubroca's polemical target-to which he was willing to sacrifice his opinions previously expressed in the biography of Louverture-remained the British, whom he accused of encouraging first colonist dissent towards France and then subsequently the slave uprising.

The tragedy of the failed expedition and the resumption of war had, however, brought about in Dubroca a sudden hardening of position. In the work on Dessalines, for example, his opinion of abolitionists had turned harsh-he accused them of encouraging division among the whites and spreading ideas of freedom throughout a savage and ferocious population who would make terrible use of them. In addition, he consigned Sonthonax, the trailblazer of abolitionism, to his own personal circle of hell 
for those who had naively believed in the possibility that the black population would at once be able to make correct use of their freedom. The pro-slavery deputy Vaublac was no longer quoted, but people of mixed race, who, in the previous work, had been treated with respect (many of them, starting with General André Rigaud, took part in Leclerc's expedition) were now placed on the same level as blacks in his all-out condemnation. The atavistic historic backwardness that all were subject to and that was previously used as a justification for France's generosity towards the slaves was now put aside. All the leaders of the black revolt-Boukman and Biassou, Jean-François and Louverture, Dessalines and Christophe-were now portrayed as immoral and ferocious, all of them utterly condemned by a judgement founded on their total disassociation from the values of civilisation. By then, the black leaders were no longer considered the champions of counter-revolution nor the instigators of a Vendée outside France. More simply, their barbaric nature placed them outside the rules of political conflict and relegated them to a condition of sheer savagery. It is useful, in this context, to make a simple verification of how many times the term africain is abused in the text: in the biography of Louverture, it appears four times, in the book on Dessalines, three times that number, and always associated with the idea of inhumanity, linked to characteristics such as brutality, barbarity, cruelty and criminality.

There was a slippage of significance here that was not, first of all, reflective of anthropological data but rather of a political agenda, since the definition of africain during the slave revolt had acquired the connotation of revolutionary radicalism. ${ }^{82}$ From this point of view, the term was connected with sauvage, which had characterised, through an indirect reference to the natives of Louisiana, those in France in Year II who had represented a violent and unnatural otherness to the profound values of the Revolution..$^{83}$ Thus, if Dessalines was portrayed as an animal-often given the features of a ferocious tiger-and the entire population of colour presented as a terrifying otherness in relation to the whites, this was the result of a judgement based on political grounds, which Dubroca thought, in that particular context, he was justified in maintaining. In other words, while it is understandably tempting to make a racist keystone of Dubroca's booklet, it is also necessary to tread with caution-something demonstrated by a specific passage in the book regarding the African tribes that constituted the slave population in Saint-Domingue. Talking about Biassou's forces, Dubroca described the Mandingos as "savage, cruel and cannibalistic nations who saw war with whites only as a means of satisfying their horrible taste for human flesh" ${ }^{84} \mathrm{It}$ would be easy to pair Dubroca's words with those of Baudry des Lozières, who also denounced Mandingo cannibalism, ${ }^{85}$ were it not the case that the passage cited above was quoted verbatim from Adonis, ou le bon nègre, ${ }^{86}$ a novel by Jean-Baptiste Picquenard. Published in 1798, this was a work that set itself the task, even within the context of the violence perpetrated during the slave revolt, of identifying the opportunity for agreement between blacks and whites on the grounds of a new Republican morality. Dubroca ransacked Adonis a number of times, in fact, but gave wide berth to the comments of Baudry des Lozières, who held Dubroca in something less than high esteem. ${ }^{87}$ Referencing Picquenard's work was useful to Dubroca in terms of recounting acts of violence through a narrative structure that ensured easy popularity with readers, but it also offered a political-ideological universe within which Dubroca could collocate his own condemnation of Dessalines. ${ }^{88}$ Picquenard had worked with Sonthonax in Saint-Domingue and his novel was indeed a eulogy to the Republic's 
civilising mission in the New World. In this regard, his ideas shared common ground with those of Louis-Sébastien Mercier, who, as is well-known, had even forecast the arrival of a black Spartacus and had opposed the slave trade and slavery in general. ${ }^{89}$ He had, however subsequently criticised the effrontery of the Société des Amis des Noirs and had distanced himself from the facile cosmopolitan illusions created by the Enlightenment. ${ }^{90}$ What is more, both Picquenard and Mercier were in agreement when denouncing Britain for instigating protest, black or white regardless, in order to destroy France's colonial ambitions, ${ }^{91}$ and they were also both following the developing situation in Saint-Domingue with trepidation. Neither of them, in any case, wished to desist from promoting Republican morality, and it was in this context that Dubroca was able to place his commentary on Dessalines.

The fact that this came out towards the end of 1804 must not mislead us into thinking that the author was handing out a sentence on an enemy who had managed to prevail over France. On the contrary, he was sure that the final confrontation was very near, and his pamphlet bringing Louverture and Dessalines together was a call for a return to Saint-Domingue in order to restore the civilisation that British strategy had sabotaged.

Things turned out differently, however, as the defeat in Saint-Domingue played into the hands of the most backward elements of Consulate political society. At that point, the dehumanisation of the rebels, which should have remained within the compass of an exclusively moral evaluation, crossed over into the field of anthropology, where it intermingled with the new racial discourse that the re-emergence of France on the colonial landscape had encouraged. ${ }^{92}$

It is no coincidence that, simultaneously with the military actions undertaken against the black rebels, moves were begun to define the new social order in the Frenchcontrolled Atlantic region. Towards the end of 1802, an important message was conveyed by Pierre-Victor Malouet, a man who had supported the revolution in 1789, had defended slavery, had taken refuge in England after the fall of the monarchy and had returned to Paris only thanks to the Brumaire coup. ${ }^{93}$ His comments on the French colonial system in the Americas, which insisted on the importance of establishing a connection between Guyana, Saint-Domingue and Louisiana, were echoed first by Pierre-Louis Berquin-Duvallon, a Saint-Domingue landowner who fled to New Orleans, ${ }^{94}$ and then, in March 1803, by Baudry des Lozières, in a second account of his travels in Louisiana..$^{95}$

50 This new book of his was an opportunity to speak above all about Saint-Domingue. Certain of an imminent recapture of the island and at odds with the philosophes de l'an II -the Year II philosophers-who had inflamed the same savage hordes in France that were now mirrored by those in America, Baudry des Lozières demanded the swift reinstatement of slavery. He went on to explain why black people were inferior even to the natives of Louisiana and put forward a social model where mixed-race people would be punished for their insubordination. ${ }^{96}$

51 Dubroca did not share this view at all-his discourse remained a Republican one. Forced to trim back arguments in support of humanitarianism, he nevertheless believed in the civilising power of revolutionary France over the obscurantist forces of the Ancien Régime, which, in Saint-Domingue, first through the actions of the colonists and later those of the black population, was making a sinister show of itself. Baudry des Lozières, on the other hand, together with all the other supporters of the slave trade, was not interested in Dubroca's tirade against the British-also slave owners-because it 
reflected a Republican outlook that he believed had encouraged the Africans' dreams of liberty. These were two opposing political lines that were bound to clash with one another in America, and with regard to America, with neither winning out over the other, as Bonaparte managed to allow them to coexist thanks to the ambiguity of his modernising plans. In this way, French civilisation intermingled its traditions with the approach of the natural sciences, which defined a rigid hierarchy of the human species and ended up creating racism and xenophobia. ${ }^{97}$ Bonaparte's disastrous American adventure thus bequeathed to $19^{\text {th }}$-century France a legacy of haughty presumption that, representing a beacon of civilisation as it did, it could therefore feel authorised to resort to force against those populations-inevitably backward and impulsive-that opposed its cultural model.

\section{Dubroca in Great Britain}

Needless to say, Dubroca's work was not successful in England. The first person to take aim at him was the Reverend Herbert Marsh, a prolific Cambridge professor, who, in 1799, painstakingly confuted Dubroca's writings on the alleged aggression by the British towards revolutionary France. In particular, Marsh emphasised the manner in which Dubroca mimicked the political views of Thomas Erskine, a London Member of Parliament close to radical circles, who had denounced Pitt's warmongering tendencies, and whose speeches against the English government had also been translated into French. ${ }^{98}$ In fact, Marsh was wrong about this: Dubroca's point of reference was actually Bertrand Barère, a former member of the National Convention, who, only a few months before him, had published a pamphlet attacking England that became the template for this ideological dispute with the enemy across the Channel. ${ }^{99}$ Among the many criticisms made by Marsh, however, one that stood out was the unreliability of the claim that London was the originator of the slave revolt in SaintDomingue. Dubroca's reasoning was, in his view, completely misplaced: it had also, claimed Marsh, been in England's interest to contain the black protests, which risked setting a dangerous example for nearby British colonies and thus destroying the whole colonial establishment in the American region. ${ }^{100}$

This stance was also in line with the benevolent neutrality of the English government towards Leclerc's expedition, given the widespread belief that the restitution of order to Saint-Domingue would benefit the entire colonial world. ${ }^{101}$ Yet, while the unacceptability of an African Commonwealth in the centre of the Americas helped bring about the Treaty of Amiens, it did not silence those in the British political sphere who feared Bonaparte's presence in America. For them, black insubordination was a thing of little account compared with French expansionism. It was a point of view expressed by Marcus Rainsford, a soldier who had served for a long time in the Caribbean. Very careful not to endorse abolitionism, he was nevertheless sympathetic towards Toussaint Louverture, claiming that he owed his life to the black governor. His support for the rebels, which led him to predict a French defeat, ${ }^{102}$ was informed by a paternalism shaped by a sense of white superiority towards the blacks. It was for this very reason that he made sure to console readers regarding the potential consequences of a rebel victory. Even if they had managed to send the French packing, the rebels would never have been able to upset the stability of the Caribbean area-their cultural 
inadequacies would have prevented them from spreading rebellion to the nearby colonies. ${ }^{103}$

Rainsford's views were shared by William Cobbett, a British journalist who had just returned from the United States, where he made a name for himself for fighting against those endorsing the democratic ideas of the French Revolution. In his newspaper, the Political Register, he criticised the Addington government for a benevolent neutrality that had something in it of complicity. He was also a supporter of slavery, although his evident contempt for black people did not prevent him from hoping that they would push back the French troops. He too believed that the creation of an African Commonwealth was not a prospect to be feared: it would not have enough power to damage the socio-economic balance in the Caribbean area. This line of thought was also shared by the staunch abolitionist James Stephen, who, in 1802, condemned the First Consul's plan to re-establish slavery in America. While he feared that a black victory would destabilise British colonies, it was an outcome that, in his view, would be preferable to a French success, which would inevitably make Bonaparte's political expansion possible in the Caribbean. ${ }^{104}$

Other people, however, saw things differently. Henry Brougham, a future proponent of the abolition of slavery in Great Britain, in a detailed review of Stephen's work, thundered against the slave trade and hoped that swift, white repopulation would help fix the damage caused by human trafficking in the Caribbean colonies. However, for this very reason, it was mandatory for Europeans to restore order in Saint-Domingue: "the negroes are truly the Jacobins of the West India Islands. They are the anarchists, the terrorists, the domestic enemy. Against them it becomes rival nation to combine, and hostile government to coalesce." He went on:

We have the greatest sympathy for the unmerited sufferings of the unhappy negroes; we detest the odious traffic which has poured their myriads into the Antilles, but we must be permitted to feel some tenderness for our European brethren, although they are white and civilised, and to deprecate the inconsistent spirit of canting philanthropy, which, in Europe, is only excited by the wrongs or miseries of the poor and the profligate; and, on the other side of the Atlantic, is never warmed but towards the savage, the mulatto and the slave. ${ }^{105}$

The English translation of Dubroca's biography of Louverture needs to be seen within the framework of a shared effort against the black spirit of rebellion in the Antilles. The initiative was Henry Delhay Symonds', a bookseller and printer who had already gained a political reputation for publishing Paine's works. The prompt appearance of the translation, just a few weeks after the original French publication, was designed to gratify the sympathies of a section of British public opinion towards Bonaparte. This is revealed by the translation of the subheading, transformed from noirs insurgés de SaintDomingue into a more general 'French rebels of St. Domingo'. Behind this variation lay the wish to insist on the political meaning of the expedition, eager to crush the black revolt to restore order (and to fully implement racial distinctions) to the Caribbean island. In any case, the work received a lukewarm reception. In July 1802, for example, the paper Monthly Review denied Dubroca any independence of judgement and highlighted the propagandist nature of his words:

According to the account before us, he [Toussaint Louverture] is a monster grown old in the perpetration of crimes; the assassin of his benefactors; hypocritical, perjured and cruel. It must be remembered, however, that this description was composed to justify the strong measures taken by the French government against him; and therefore, though the atrocities of which this Negro Chief has been guilty 
would be sufficiently horrible, were they related without the least exaggeration, the pages of M. Dubroca must be read with caution. ${ }^{106}$ French government. Even harsher, however, was the Critical Review's contribution, which voiced the opinions of the abolitionists and regarded the expedition sent by Bonaparte with great suspicion:

The life of a Black written by a White, the picture of the lion painted by the man [...] Toussaint is here represented as a complete hypocrite [...] from a writer who delights in such expressions, it is in vain to expect an impartial narrative. The whole is a caricature, not a character. Yet, even in the attempt to make the poor Black still blacker, the slave is far inferior in ferocity, cruelty and vice to the heroes of the great nation, who have proved to mankind that all the boasted effects of civilised life cannot tame the heart of a White, who, when he throws off all restraints of religion and virtue, is not to be distinguished from the most vicious Black, but by superior art in increasing his crimes. ${ }^{107}$

This contribution was clearly influenced by James Stephen, who, in the meantime, had written a laudatory portrayal of Louverture in which Dubroca was fiercely accused of being at Bonaparte's service in slandering an honourable man. ${ }^{108}$ Public opinion soon sided with the black governor, as demonstrated by the appearance of many journalistic efforts in Louverture's support. ${ }^{109}$ This was quickly followed by the publication in Germany of yet another book on Toussaint Louverture which, although purporting to be a biography, was a wholly fictionalised account. ${ }^{110}$ In other words, if the publication of Dubroca's pamphlet in the English language was supposed to act as a promotional operation to the benefit of the First Consul, its outcome could not have been more disappointing.

This did not mean, however, that, in Britain, the rebels' cause immediately created much of a following. In 1803, in a voluminous book about issues regarding the slave trade, Brougham again claimed that it was entirely in Europe's interest for France to succeed in reasoning with the rebels. ${ }^{111}$ The following year, he reiterated that black independence would not solve, but rather intensify, a problem originally caused by the slave trade, which had brought an astounding number of Africans to the Caribbean region. ${ }^{112}$ The resumption of the war, however, worked in the rebels' favour. The Camp of Boulogne and the threat of invasion led the British press to close ranks on the necessity of a naval blockade in Saint-Domingue to prevent the French from obtaining reinforcements. In the context of direct support to the Africans rebelling against Bonaparte, James Stephen hastened back to his printing press and published first the abovementioned biography of Louverture and, shortly thereafter, an appeal for a prompt alliance between England and Haiti. ${ }^{113}$ In reality, the London government, reassured that revolutionary contagion would not spread among New World slaves, saw things rather differently. In fact, it adopted the line of those who believed that the birth of an African Commonwealth-one with which they could immediately draw up profitable commercial agreements-was on balance a fair price to pay for putting an end to Bonaparte's adventure in the Caribbean. At the very time that the French capitulated, Lord Hobart, Secretary of State for War and the Colonies, wrote to the Jamaican Governor, George Nugent:

If you can secure the proposed commercial intercourse, and restrain the brigands from getting upon the water, the establishment of a black government at St. Domingo will be less dangerous to Jamaica than that of the French-Your situation must at any rate have been delicate-but all circumstances considered (provided 
the French are forced to evacuate) I should say the result was as favourable as we cou'd have wished. ${ }^{114}$

Hobart's words confirm that the English government believed that Dessalines could not be a partner in a political dialogue and that his actions could easily be contained. Shortly after, the first reports of the massacres perpetrated on the whites were, therefore, seen as a confirmation of the bestial and ferocious nature of the blacks. In spite of Stephen's attempts to mitigate the events, ${ }^{115}$ British public opinion was soon overwhelmed with news regarding rebel barbarity and atrocity. ${ }^{116}$ William Cobbett was confirmed in his hatred of black people, indiscriminately portrayed as an inferior race that was only capable of obeying and for whom the 1789 edicts merely provided an opportunity to demonstrate their insuppressible bestiality. For Cobbett, the French Revolution was always in the dock as one of the accused: accountable not just for the Terror, for the violence on the common people of Paris and for the wars in Europe, but also for the brutal uprising of the African slaves in the New World. The triumph of the blacks was the umpteenth confirmation of the nefarious consequences of revolutionary concepts applied to those-whites, too, but mostly blacks-who lacked a fully rounded civilisation. ${ }^{117}$

Within this context, a very hostile one for the rebels, in 1805, Marcus Rainsford again addressed the subject of Saint-Domingue. He expanded his work from 1802, converting it into a history of Haiti's birth, ${ }^{118}$ while keeping Toussaint Louverture at the centre of the work, a man whose inner strength and generosity represented the most distinctive features of his personality. Dessalines, who was nevertheless the founder of Haiti's black republic, remained in the background and was presented only as Louverture's fortunate emulator. This thematic choice proves that Rainsford, although officially writing about Haiti's origins, was actually addressing the British audience about the dramatic confrontation-not just military-that had occurred in the Caribbean between France and Britain.

In his reconstruction, the history of the colony's independence and the birth of a black republic was interpreted as resulting from a clash between the European powers of that period-losing, thereby, any possible historical autonomy. The very fact of placing Louverture at the centre of the narrative for his human qualities rather than for his political profile reveals how Rainsford's polemical target was revolutionary France, held accountable for attacking the black governor for not following the rules of Republican policies. This originality of his had been the real cause of Louverture's demise, and Dubroca's biography, which Rainsford labelled 'distorted for the purposes of party', ${ }^{119}$ was indeed proof of it, with all the accusations made against the black governor arising from ideological prejudice. This outlook becomes apparent when examining the manner in which Rainsford subordinates practical revolutionary policy to skin colour parameters.

In his work, the banner of equality was carried not only by white Jacobins but rather by all the mixed-race people, who-if it is possible-had managed to outdo the former in terms of violence, extremism and wickedness. ${ }^{120}$ That was the case of Ogè, who had tried in vain to orchestrate an uprising in 1790, but mostly of General Rigaud-always on the side of the Republic, opponent of the English and rival to Toussaint, and who was portrayed as a brave man, but, above all, cruel. ${ }^{121}$ In Rainsford's narrative, compared to the revolutionary extremism of certain whites and of all mixed-race people, the blacks constituted a world apart, driven to violence in the name of freedom 
but ultimately incapable of autonomous political decisions. Barbarity, thus, played a role in absolving the blacks, while also valorising Louverture, alone amongst his peers to have overcome the barrier of ignorance. In this way, he had found entry into the civilised world and obtained the cultural identity of the whites without embracing the violence of the Jacobins and their mixed-race comrades.

From this point of view, Louverture's profile anticipated the prerequisite for British colonial policy in the $19^{\text {th }}$ century to seek out a locally-based ruling class that could be assimilated to a European lifestyle. In this respect, Rainsford's stance, albeit from a diametrically opposite point of view, linked up with Dubroca's. In their accounts, they both portrayed Louverture as a man who, thanks to education, had managed to step beyond the historical limitations of his people and subsequently enter European society. Only when analysing his actions as governor did their ideas diverge. In Dubroca's opinion, Louverture was a traitor who had disavowed the values of equality in order to rush into an agreement with the English; in Rainsford's view, he was the embodiment of how the values of freedom clashed with the revolutionary narrative of France.

Both considered Louverture to be a civilised man, and this characteristic distinguished him from his fellow blacks-neither Rainsford nor Dubroca questioned their inferiority. It was not difficult to conclude, therefore, that only a violent internal conflict between European whites had made it possible for some black slaves to come to prominence on the landscape of international politics: a slave revolution in Saint-Domingue had never existed, and Haiti's black republic was only the random by-product of political conflict taking place elsewhere. After 1804, in both France and Britain, Haiti seemed merely to be an incident along the way, an isolated event, the outcome of a sudden rash, rebellious gesture that would soon be forgotten by history. In the arrogance with which European powers looked on Saint-Domingue' independence lay the immediate reasons for the silence that followed the birth oh Haiti.

\section{NOTES}

1. See David A. BELL, Men on Horseback. The Power of Charisma in the Age of Revolution, New York, FSG, 2020, p. 95-112. I am particularly indebted to David Bell for his comments on an earlier draft and his incredibly helpful suggestions.

2. See for an excellent definition of the Directory's political action as an 'Empire républicain', Pierre SERNA, "Lorsque la loi fait la révolution aux Colonies... ou l'empire des lois républicaines," dans François Régent, Jean-François Niort \& Pierre Serna, Les colonies, la Révolution Française, la loi, Rennes, PUR, 2014, p. 276.

3. "The French are now in possession of the whole island of St. Domingo with all their former settlements in that quarter and Louisiana is ceded in sovereignty to the republic; so in all probability are the Florida; with these possessions, she is indisputably mistress of the Gulf of Mexico". Sketches on the Intrinsic Strength, Military and Naval Force of France and Russia; with Remarks on their Present Connexion, Political Influence and Future Projects, Hague, 1803, p. 57. For an opposite interpretation of the international political situation, see George ORR, The Possession of Louisiana by 
the French, considered, as it affects the interests of those nations more immediately concerned, London, 1803, p. 13: "The French Consul [...] stands, or at least would wish to stand, like the Colossus of Rhodes, with one foot on the western, and the other on the eastern hemisphere, grasping at both as far as his power will allow, though his means are unequal to his wishes, while the British navy opposes to his gigantic plans an insurmountable obstacle".

4. Philippe R. GIRARD, The Slaves Who Defeated Napoleon. Toussaint Louverture and the Haitian War of Independence, 1801-1804, Tuscaloosa, University of Alabama Press, 2011, p. 44-45.

5. Béatrice LAURENT, "A toponymic conquest? The British presence in Martinique 1794-1802," Cultures of the Commonwealth, no. 19/20/21, 2016-2017, p. 67-77.

6. William S. CORMACK, Patriots, Royalists, and Terrorists in the West Indies. The French Revolution in Martinique and Guadeloupe,1789-1802, Toronto, University of Toronto Press, 2019, p. 254-255.

7. Philippe GIRARD, "Napoléon Bonaparte and the Emancipation Issue in Saint-Domingue, 1799-1803", French Historical Studies, vol. 32, no. 4, 2009, p. 587-618.

8. Alyssa SEPINWALL, "The specter of Saint Domingue: American and French Reactions to the Haitian Revolution," in David P. Geggus \& Norman Fiering (eds.), The World of the Haitian Revolution, Bloomington, Indiana University Press, 2009, p. 317-318.

9. François-Alphonse AULARD, "Un document sur l'histoire de la presse. La préparation de l'arrêté du 27 nivôse an VIII," Révolution française, vol. 44, no. 1, 1903, p. 78-82 and Carla HESSE, Publishing and Cultural Politics in Revolutionary Paris, 1789-1810, Berkeley, University of California Press, 1991, p. 169.

10. Jean-Luc CHAPPEY, "Les sociétés savantes à l'époque consulaire," Annales historiques de la Révolution française, no. 309, 1997, p. 451-472.

11. It is worth noting how many journalists in the first years of the Restoration were called girouettes (weather vanes) for the way their loyalty swung from Napoleon to Louis XVIII. See Pierre SERNA, La République des girouettes. 1789-1815, et au-delà : une anomalie politique, la France de l'extrême centre, Seyssel, Champ Vallon, 2005.

12. On this topic, see particularly David A. BELL, The Cult of the Nation in France: Inventing Nationalism, 1680-1800, Cambridge MA, Harvard University Press, 2001, p. 78-92; Edmond DZIEMBOWSKI, Un nouveau patriotisme français, 1750-1770. La France face à la puissance anglaise à l'époque de la guerre de Sept Ans, Oxford, Voltaire Foundation; University of Oxford, 1998, p. 62-67; and John Shovlin, "Selling American Empire on the Eve of Seven Years War: The French Propaganda Campaign of 1755-1756," Past \& Present, no. 206, 2010, p. 121-149.

13. For a list of all his works, see Joseph-Marie QUERARD, La France littéraire, Paris, chez Firmin Didot Frères, 1828, vol. 2, p. 611-613.

14. See especially Chris BongIE, Friends and Enemies. The Scribal Politics of Post/Colonial Literature, Liverpool, Liverpool University Press, 2009, p. 69-74; Deborah JENSON, "Jean-Jacques Dessalines and the African Character of the Haitian Revolution," William and Mary Quarterly, no. 3, 2012, p. 624-627; Marlene DAUT, Tropics of Haiti. Race and the Literary History of the Haitian Revolution in the Atlantic World, 1789-1865, Liverpool, Liverpool University Press, 2015, p. 69-70.

15. Chris BONGIE, Friends and Enemies, op. cit., p. 71.

16. Regarding this matter, see Manuel BARCIA, "From Revolution to Recognition: Haiti's Place in the Post-1804 Atlantic World," American Historical Review, vol. 125, no. 3, 2020, p. 899-905.

17. Michel-Rolph trouillot, Silencing the Past: Power and the Production of History, Boston, Beacon Press, 1995, p. 82.

18. For the reverberations of the Haitian Revolution in Cuba, Ada FERRER, Freedom's Mirror. Cuba and Haiti in the Age of Revolutions, Cambridge, Cambridge University Press, 2014, p. 52-54.

19. James Alexander DuN, Dangerous Neighbors. Making the Haitian Revolution in Early America, Philadelphia, University of Pennsylvania Press, 2016, p. 179-202; and Consuelo Naranjo Orovio, "Le fantasme d'Haïti: l'élaboration intéressée d'une grande peur," in Alain Yacou (ed.), Saint- 
Domingue espagnol et la révolution nègre d'Haïti, Paris, 2007, p. 637-665. See also Sibylle FISCHER, Modernity Disavowed: Haiti and the Cultures of Slavery in the Age of Revolution, Durham, Duke University Press, 2004, p. 7-13.

20. Jeremy POPKIN, Facing Racial Revolution. Eyewitness Account of the Haitian Revolution, Chicago, University of Chicago Press, 2007, p. 1-3.

21. See Yun KYOUnG KWON, "When Parisian Liberals spoke for Haiti: French Anti-Slavery Discourses on Haiti under the Restoration, 1814-1830," Atlantic Studies, vol. 8. no. 3, 2011, p. 317-320.

22. Understanding this way of apprehending the events is the best illustration of the historiographical changes that followed the pivotal works by Carolyn FICK, The Making of Haiti. The Saint-Domingue Revolution from Below, Knoxville, University of Tennessee Press, 1990; and Laurent DUBoIs, Avengers of the New World. The Story of the Haitian Revolution, Cambridge, Harvard University Press, 2004.

23. As already suggested by Deborah JENSON in "Jean-Jacques Dessalines and the African Character," William and Mary Quarterly, vol.69, no. 3, 2012, p. 626, Louis Dubroca is the same person as Jean-François Dubroca: see the latter's act of marriage with Marie Françoise Thérèse Lecomte on $7^{\text {th }}$ July 1801 , which confirms he resided at the same address as his bookshop. In fact, the only works signed L. Dubroca were published in the 1820s by his wife (or widow?) Madame Lecomte-Dubroca and very probably should be ascribed to her (as a nom de plume) or to their son, Charles Horace, born in 1803, an actor at the Comédie-Française known under the name of Lecomte, i.e. his mother's maiden name. See Archives nationales (AN hereafter), Paris, MC/ET/ XCIII, cart. 235 (Contrat de mariage de Jean-François Dubroca, libraire, 1760, rue de Thionville, divorcé d'avec Claudine Françoise Rose, avec Marie Françoise Thérèse Lecomte, 38 rue des DeuxÉcus, 19 messidor an IX). See also Roméo ARBOUR, Dictionnaire des femmes libraires en France, 1470-1870, Genève, Droz, 2003, p. 330 and L'intermédiaire des chercheurs et curieux, vol. 36, 1900, p. 229.

24. Jean-François Dubroca was still a priest in 1792 when, on the morning of $21^{\text {st }}$ August, in the Parisian church of St. Sulpice, he delivered a eulogy for the people who lost their lives during the insurrection which took place on $10^{\text {th }}$ August: see Discours prononcé à Paris, le 21 août 1792, dans le temple catholique de Saint-Séverin, jour du service funèbre des victimes du 10 août, par M. Dubroca, citoyen et prêtre, s.l., s.d. [Paris, 1792]. See also Jean-Pierre BERTAUD, Un jour, un homme, la Révolution, Paris, Robert Laffont, 1988, p. 231-232. He left the priesthood in the following months, because, on $18^{\text {th }}$ February 1793 , he married Claudine Françoise Roze. It is very probable that it was Dubroca himself who delivered a speech to the Convention accepting the constitution of 1793 on behalf of invalid soldiers. See DUBRoCA, Discours prononcé à la Convention nationale pour l'acceptation de l'acte constitutionnel par les militaires invalides... Séance du 5 août 1793, Paris, Imprimerie nationale, 1793. Profound thanks to Thomas Lefèvre for his valuable genealogical researches.

25. Albert MATHIEZ, La théophilantropie et le culte décadaire, 1796-1801. Essai sur l'histoire religieuse de la Révolution, Paris, Félix Alcan éditeur, 1903, p. 262-263.

26. [Henri] GRÉGOIRE, Histoire des sectes religieuses, Paris, Baudouin Frères éditeurs, 1826, tome 2, p. 104: "Dubroca, ex Barnabite: he is the author of numerous works; he is the finest orator amongst them."

27. Jean-Luc CHAPPEY, "Le Portique Républicain et les enjeux de la mobilisation des arts autour du Brumaire an VIII," in Philippe Bourdin and Gérard Loubinoux (eds.), Les arts de la scène et la Révolution française, Clermont Ferrand, PUBP, 2004, p. 487-507.

28. DUBRoCA, Éloge de Washington, Paris, N.-L.-M. Des Essarts, Year VIII (1799). See the report of the meeting in Ami des Lois, no. 1644, 19 ventose VIII (March 10, 1800), p. 3: "The American representatives who found themselves at the meeting refused the seats that had been assigned to them and they mixed themselves with the rest of the audience." 
29. It is worth noting how Albert MATHIEZ, in La théophilantropie..., op. cit., p. 629-632, referring to Dubroca's speech, asserted that he had misunderstood the political situation caused by the coup of Brumaire and had only succeeded in underlining his own sense of republicanism. See also, for a positive review, L'Ami des Lois, no. 1667, Primidi II Germinal Year VIII (April 1, 1800), p. 4: "Praising a great man is useless; saying what he has done and saying it with dignity and with the passion of a strong and virtuous soul is the only thing that is necessary and it is what Dubroca has done."

30. Journal typographique et bibliographique, vol. 3, no. 20, 10 Ventôse Year VIII [March 1, 1800], p. 157.

31. DUBRocA, La politique du gouvernement anglais dévoilée, Paris, Des Essarts, Year VI (1798). Dubroca had begun to collaborate with Des Essarts in 1797 and he continued to do so until he opened his own bookshop in 1801. His first work for Des Essarts was the revision of a compilation of natural history written in jail by a victim of the Terror: see Entretiens d'un père avec ses enfants sur l'histoire naturelle, ornés de quatre cent figures, Paris, Des Essarts, 1797, 1:vi. See also, in collaboration with the same publisher, DUBROCA, Discours sur divers sujets de morale, pour les fêtes nationales, Paris, Des Essarts, 1799.

32. See Antoine boUlAy DE LA MEURTHE, Essai sur les causes qui, en 1649, amenèrent en Angleterre l'établissement de la République, Paris, Baudouin, 1799. On the role played by the English precedent during the crucial juncture of 1799 in France, see Pierre Serna, "1799. Le retour du refoulé ou l'histoire de la Révolution anglaise à l'ordre du jour de la crise du Directoire," in Philippe Bourdin (ed.), La Révolution, 1789-1871. Écriture d'une histoire immédiate, Clermont-Ferrand, PUBP, 2008, p. 224-232.

33. Both of them were published with a sketch concerning the London police as Mélanges historiques et politiques sur l'Angleterre, Paris, Des Essarts, 1801.

34. Ami des Lois, no. 1615, 20 Pluviôse Year VIII (February 9, 1800), p. 2.

35. Gazette nationale ou Moniteur universel, no. 82, 22 Frimaire Year VIII (December 12, 1799), p. 325-326. See also Andrew JAINCHILL, Reimagining Politics After the Terror. The Republican Origins of French Liberalism, Ithaca, Cornell University Press, 2008, p. 225-226.

36. DUBROCA, La politique du gouvernement anglais dévoilée, op. cit., p. 93-96.

37. Louis-Sébastien MERCIER, Le Nouveau Paris, Paris, Fuchs, Pougens et Cramer, 1797, tome 2, p. 83-6.

38. Journal des Hommes libres, 16 Messidor Year VIII [July 5, 1800], no. 220, p. 887.

39. Règlement de la Société libre des sciences, lettres et arts de Paris et liste des membres composant la société pour l'an IX de la République française, Paris, imprimerie de Mme Huzard, 1801, p. 26: Dubroca is listed as a member of the Portique républicain. For his considerations regarding the theophilanthropic cult, see [Henri] GRÉGOIRE, Histoire des sectes, op. cit., tome 2, p. 104: "He himself declares that the theophilantropic cult having been established at a time when the factions were still in ferment, he soon realized that theophilantropy was all the more dangerous, as Religion was the pretext and the veil; that as soon as he saw this, he withdrew and became the object of relentless hatred."

40. AN, série F17, boîte 1330, dossier Dubroca.

41. For Dubroca's oratory school, opened at 8 rue Christine, see Gazette nationale ou Moniteur universel, no. 212, 2 Floréal Year III (April 22, 1805), p. 4.

42. [DUBROCA], La vie de Bonaparte premier consul de la République française et pacificateur de l'Europe, depuis sa naissance jusqu'au 18 Brumaire Year 10, époque de la paix générale, précédée d'un hommage à la paix, Paris, Bonneville, 1801.

43. DUBRoCA, Discours sur la paix, prononcé dans plusieurs temples de Théophilanthropie le 30 frimaire de l'an VI de la République Française, Paris, chez l'Auteur, 1797. 
44. See Journal typographique et bibliographique, vol. 5, no. 16, 30 Nivôse Year X [January 20, 1802], p. 125.

45. See the police reports dated respectively $19^{\text {th }}$ and $24^{\text {th }}$ November 1801 reproduced in François-Alphonse AULARD, Paris sous le Consulat. Recueil de documents pour l'histoire de l'esprit public à Paris, Paris, L. Cerf, Noblet et Quantin, 1901, tome 2, p. 613 and 624.

46. Ibid., p. 780, 783-785, 795, 802-803 (all reports of March 1802).

47. DUBRoCA, La vie de Toussaint Louverture, chef des noirs insurgés de Saint-Domingue, Paris, Dubroca et Bonneville, 1802. See the advertisement for it in the Gazette nationale ou Moniteur universel, vol. 29, no. 191, 11 Germinal Year X [April 1, 1802], p. 766, and in the Journal typographique et bibliographique, vol. 5, no. 28, 30 Germinal Year X [April 20, 1802], p. 224.

48. Ibid., p. 36. See the English translation: "I have no intention, in citing this paragraph, to blame or misrepresent the English nation, which, at that time the enemy of France, had the incontestable right to sustain itself by such alliances as it could make; my design is to shew the profound dissimulation and perfidy of Toussaint." DUBROCA, The Life of Toussaint Louverture, Chief of the French [sic] Rebels of St. Domingo, London, Dubroca, 1802, p. 38-39.

49. See [Charles-Yves] cousin D'AVALLon, Histoire de Toussaint Louverture, chef des noirs insurgés de Saint-Domingue, Paris, chez Pillot frères, 1802, and [unknown], Vie privée politique et militaire de Toussaint Louverture par un homme de sa couleur, Paris, rue de la Parcheminerie, 1801. Both of them -as we shall see in the following pages-were printed a few weeks after the publication of Dubroca's pamphlet. See the advertisement for both in Journal typographique et bibliographique, vol 5, nos. 29-30, 8 Floréal Year X [April 28, 1802], p. 239.

50. DUBRoCA, Anföraren för de upproriska negrerna på Domingo, Toussaint-Louvertures lefverne, Stockholm, tryckt hos Carl Delén, 1802.

51. [DUBRoca], The Life of Toussaint Louverture, late General in Chief and Governor of the Island of San Domingo, Charleston, T.B. Bowen, 1802. For some remarks on Nicholas Laurent Michel Herbemont, among the finest practicing winemakers of the early United States, refer to David S. SHIELDS (ed.), Pioneering American Wine: Writings of Nicholas Herbemont, Master Viticulturist, Athens, University of Georgia Press, 2019, p. 16.

52. Quoted by Malick Ghachem in his review of Ronald Angelo JoHnson, Diplomacy in Black and White: John Adams, Toussaint Louverture, and Their Atlantic World Alliance, Athens, University of Georgia Press, 2015: see Journal of Southern history, vol. 81, no. 2, 2015, p. 448. However, Arthur Scherr has underlined how Adams was critical to Louverture's victory against general Rigaud in March 1800 and was consequently interested in re-evaluating someone greatly sustained by his presidency: see Arthur SCHERR, John Adams, Slavery and Race. Ideas, Politics and Diplomacy in an Age of Crisis, Santa Barbara, Praeger, 2018, p. 181.

53. An interpretation revived by Pierre PLUCHON, Toussaint Louverture, un révolutionnaire noir d'Ancien Régime, Paris, Fayard, 1989.

54. Malick GHACHEM, “The Colonial Vendée," The World of the Haitian Revolution, op. cit., p. 171.

55. [DUBROCA], La vie de Toussaint Louverture, op. cit., p. 34, 43 and 67.

56. See Kerversau report to the minister Decrès dated 1 Germinal Year IX [March 22, 1801] reproduced in David GEGGUS (ed.), The Haitian Revolution. A Documentary History, Cambridge, Hackett, 2014, p. 120-122.

57. Philippe R. GIRARD, The Slaves Who Defeated Napoleon..., op. cit., p. 37-39.

58. "We have read it and it is only a violent complaint written by Sonthonax or one of his peers; it is a web of lies and invented facts and from the way it has been written, it is easy to see the opinions of who composed it," Vie privée politique et militaire de Tousaint Louverture, op. cit., p. 10.

59. [DuBroca], La vie de Toussaint Louverture, op. cit., p. 42. On this topic, see Deirdre COLEMAN, "The Cultural Afterlives of Toussaint Louverture and the Haitian Revolution," in Neil Ramsey and 
Gillian Russell (eds.), Tracing War in British Enlightenment and Romantic Culture, London, Palgrave Macmillan, 2015, p. 78-80.

60. Bernard GAINOT, "Le général Laveaux, gouverneur de Saint-Domingue, député néo-Jacobin," Annales historiques de la Révolution française, no. 278, 1989, p. 433-454.

61. DUBRoCA, Les femmes célèbres de la Révolution, Paris, chez l'Auteur, 1802.

62. DUBROCA, L'itinéraire des Français dans la Louisiane, contenant l'histoire de cette colonie française, sa description, le tableau des mœurs des peuples qui l'habitent, Paris, chez l'Auteur, 1802.

63. Nathalie DESSENS, From Saint-Domingue to New Orleans: Migration and Influence, Gainesville, University Press of Florida, 2007, p. 112-113.

64. René LE GARDEUR, “The Saint Domingue Refugees in Louisiana, 1792-1804," in Carl A. Brasseaux and Glenn R. Conrad (eds.), The Road to Louisiana: The Saint-Domingue Refugees, 1792-1809, Lafayette, Center for Louisiana Studies, University of Southwestern Louisiana, 1992, p. 151.

65. Louis-Narcisse BAUDRY DES LOZIÈRES, Voyage à la Louisiane et sur le continent de l'Amérique septentrionale, fait dans les années 1794 à 1798, Paris, Dentu, 1802, p. 147-148 and 191-199.

66. Pierre SERNA, Comme des bêtes. Histoire politique de l'animal en Révolution, 1750-1840, Paris, Fayard, 2017, p. 326-330.

67. DUBRoCA, L'itinéraire des Français dans la Louisiane..., op. cit., p. 92.

68. Louis-Sébastien MERCIER, L'an deux mille quatre cent quarante. Rêve s'il en fût jamais, Paris, an VII [1786], tome 3, p. 74-77.

69. DUBROCA, L'itinéraire des Français dans la Louisiane..., op. cit., p. 3-4.

70. Dubroca, La civilité puérile et honnête, à l'usage des enfans des deux sexes, Paris, Dubroca, s.d. [1802]; [D'ANGLESY], Le guide du jeune militaire[...]: nouvelle édition, refondue et augmentée d'un très grand nombre de faits mémorables puisés dans l'histoire de la Révolution, Paris, Dubroca, 1802; [collective work], De l'éloquence de la chaire, ou Nouveau manuel des orateurs sacrés, Paris, Dubroca, 1803; DUBROCA, Nouvelle géographie élémentaire de la France d'après son organisation actuelle... suivie d'un abrégé de la géographie universelle, Paris, Dubroca, 1803; ID., L'histoire universelle de Bossuet, exposée par demandes et par réponses, en faveur des écoles et des familles chrétiennes, précédée d'une instruction élémentaire sur l'étude de l'histoire, Paris, Dubroca, 1803.

71. DUBROCA, Principes raisonnés sur l'art de lire à haute voix; suivis de leur application particulière à la lecture des ouvrages d'éloquence et de poésie, Paris, Dubroca, 1802. This is the most authoritative of Dubroca's numerous works: see Leslie DE'ATH, "Language and Diction: Dubroca's Traité and French style soutenu in the Nineteenth Century," Journal of Singing, vol. 66, no. 1, 2009, p. 63-70 and no. 2, 2009, p. 171-180.

72. DUBROCA, Mémoires pour servir à l'histoire des attentats du gouvernement anglais, contre toutes les puissances de l'Europe et particulièrement contre la France depuis le commencement de la Révolution jusqu'à ce jour, Paris, Dubroca, 1803.

73. See Journal typographique et bibliographique, vol. 6, no. 37, 8 Messidor Year XI (June 27, 1803), p. 293: "The circumstances at the moment really recommend this text."

74. See, for example, Pierre-François BARBAULT-ROYER, Résumé sur l'Angleterre, Paris, Galland, s.d. and Jean CHAS, Réflexions sur l'Angleterre, Paris, s.d. [1803], p. 24: "It is the English government that has armed the black people of St. Domingue and the one that has covered that colony in ruin and ashes. The English government has recognized both the authority and the usurpation of that man spewned out from hell to spread fires, proscription and death on that unlucky land."

75. Journal général de la littérature de France, tome 6, 1803, p. 314.

76. DUBRoCA, Mémoires pour servir à l'histoire..., op. cit., p. 8-10 and 195-198.

77. DUBRocA, Les constitutions de l'Empire français, précédées d'une instruction historique (...), Paris, 1804. 
78. Dubroca, La vie de J.-J. Dessalines, chef des noirs révoltés de Saint-Domingue, Paris, Dubroca, 1804. See the advertisement for it in Journal typographique et bibliographique, vol. 8, no. 15, 10 Frimaire Year XIII (December 1, 1804), p. 116.

79. DUBRoCA, Lebens des J.J. Dessalines oder Jacob's der Ersten, Kaysers von Haiti, St. Domingo, Leipzig, Bey J.C. Hinrichs, 1805; see also "Geschichte der Neger Empörung auf St. Domingo unter den Unfuhrung von Toussaint Louverture und Jean-Jacques Dessalines," Minerva, no. 1, 1805, p. 434-465; Het Leven van Jean-Jacques Dessalines hopperoofd der opgestane negers van St. Domingo, Haarlem, Bohn, 1805; Vida de J. J. Dessalines, jefe de los negros de Santo Domingo. Con notas muy circunstanciadas sobre el origen, caracter y atrocidades de los principales gefes de aquellos rebeldes desde el principio de la insurreccion en 1791, Madrid, La Imprenta real, 1805.

80. Alicia V. RAmirez olivares, "Dessalines y Santo Domingo en la Nueva España, de la libertad al horror," Graffylia, no. 5, 2005, p. 108-114. See also, for the drawings inserted in the Mexican edition of Dubroca's work, Kelly DONAHUE-WALLACE, "Ilustrando el terror de rebellion. Los grabados de la Vida de J. J. Dessalines," in Fernando Guzmàa Schiappacasse, Gloria Cortés Aliaga and Juan Manuel Martiínez Silva (eds.), Arte y crisis en Iberoamérica, Santiago, Ril editores, 2004, p. 85-91; Alejandro E. GómEz, "Images de l'apocalypse des planteurs", L'ordinaire des Amériques, no. 215, 2013, p. 29-32.

81. Dubroca, Vida de J. J. Dessalines, jefe de los negros de Santo Domingo. Con notas muy circunstanciadas sobre el origen, caracter y atrocidades de los principales gefes de aquellos rebeldes desde el principio de la insurreccion en 1791, México, M. de Zúñiga y Ontiveros, 1806, Introduccion: “How important it is to have union between all of the whites in a colony where blacks and other races are also present. The division of the whites native to that island allowed the blacks to conquer it and caused the death of the whites at their despicable hands after many instances of violence born out of a horrifying cruelty. Unhappy Europeans and Creoles! Poor victims! How it cost you to have believed the promises of Louverture the hypocrite and of the fierce Dessalines! And you, supporters of Great Britain, who pay attention to English emissaries sent from the island of Jamaica, observe the advantages of a nation that has [...]sacrificed you for its vile interests, ridiculing your dreams of liberty and independence".

82. Vertus SAINT-LOUIS, "Le surgissement du terme 'africain' pendant la révolution de SaintDomingue," Ethnologies, vol. 28, no. 1, 2006, p. 163-167.

83. For a detailed exam of this political topic in the Thermidorean political culture, see Sergio LUZZATTO, L'autunno della rivoluzione. Lotta e cultura politica nella Francia del Termidoro, Torino, G. Einaudi, 1994, p. 180-194.

84. DUBRoCA, La vie de J.-J. Dessalines..., op. cit., p. 14.

85. Louis-Narcisse BAUDRY DES LOZIÈRES, Les égarements du nigrophilisme, Paris, chez Migneret imprimeur, 1802, p. 143.

86. Jean-Baptiste PICQUENARD, Adonis ou le bon nègre. Anecdote colonial, Paris, 1798, p. 45-46. Dubroca's plagiarism has already been highlighted by Youmna CHARARA, Fictions coloniales au XVIII siècle, Paris, L'Harmattan, 2005, p. 189-190, and by Chris BONGIE, Friends and Enemies. The Scribal Politics of Post/Colonial Literature, Liverpool, Liverpool University Press, 2008, p. 72-73. See also Chris Bongie's introduction to Jean-Baptiste PICQUENARD, Adonis suivi de Zoflora et de documents inédits, Paris, L'Harmattan, 2006, p. vii-xlvi.

87. It is worth noting that Baudry des Lozières disdained Dubroca's Itinéraire, asserting that it was a compilation written by somebody who had never visited Louisiana: Louis-Narcisse BAUDRY DES LOZIÈRES, Voyage à la Louisiane et sur le continent de l'Amérique septentrionale (...), Paris, Dentu, 1802, p. 264.

88. See the representation of the character of the reactionary priest Philémon as another example of the plagiarism demonstrated by Dubroca towards Picquenard: Jean-Baptiste 
PICQUENARD, Adonis ou le bon nègre..., op. cit., p. 137-141 and DUBROCA, La vie de J.-J. Dessalines... op. cit., p. 29-31.

89. Marcel DORIGNY, "Antislavery, Abolitionism and Abolition in France from the end of the $18^{\text {th }}$ century to the 1840s," in Pascal Blanchard, Sandrine Lemaire, Nicolas Bancel and Dominic Thomas (eds.), Colonial Culture in France since the Revolution, Bloomington, Indiana University Press, 2014, p. 62-63.

90. Laure MARCELLESI, “Louis-Sébastien Mercier: Prophet, Abolitionist, Colonialist," Studies in Eighteenth-Century Culture, no. 40, 2011, p. 247-273.

91. Jean-Baptiste PICQUENARD, Adonis ou le bon nègre..., op. cit., p. 60; and Louis-Sébastien MERCIER, Le Nouveau Paris..., op. cit., p. 208.

92. Jean-Luc CHAPPEY, La Société des Observateurs de l'homme (1799-1804). Des anthropologues au temps de Bonaparte, Paris, Société des études robespierristes, 2002; and Pierre SERNA, "Tenir les noirs à l'œil. Hypothèse pour une 'iconoirlogie'," Annales historique de la Révolution française, no. 395, 2019, p. 71-191.

93. Pierre-Victor MALOUET, Collection de mémoires et correspondances officielles sur l'administration des colonies: et notamment sur la Guiane française et hollandaise, Paris, Baudouin, 1802, vol. 4. On Malouet and the circles sustaining slavery in Bonaparte's France, see Yves BENOT, La démence coloniale sous Napoléon, Paris, La Découverte, 1992, p. 189-192.

94. Pierre-Louis BeRQUin-DUVAllon, Vue de la colonie espagnole du Mississipi ou des provinces de Louisiane et Floride occidentale en l'année 1802, par un observateur résident sur les lieux, Paris, L'imprimerie expéditive, 1803, p. 254-255: "It is a kind of men whom nature seems to have destined for slavery, by the turn of their mind, their disposition to let themselves be led, their moral incapacity, and, so to speak, a particular direction, an innate propensity, an elastic tendency, in them, towards a purely passive state, in that entirely different from the savages or natives of America, as opposed to subjection as the negroes are naturally compatible with it."

95. Louis Narcisse BAUDRY DES LOZIÈRES, Second voyage à la Louisiane faisant suite au premier de l'auteur de 1794 à 1798, Paris, chez Charles imprimeur, 1803.

96. Ibid., p. 209-211 and 242-243.

97. Pierre SERNA, Comme des bêtes..., op. cit., p. 319-330.

98. Herbert MARSH, La politique dévoilée de la France vis-à-vis de l'Angleterre, London, 1799, tome 1, p. 93-97. See also [Thomas] ERSKINE, Coup d'œil sur les causes et les conséquences de la guerre actuelle avec la France, London, J. Debrett and Paris, Laran, 1799.

99. Bertrand BARÈRE, La liberté des mers, ou le gouvernement anglais dévoilé, Paris, 1798. See also Bertrand BARÈRE, Rapport sur les crimes de l'Angleterre envers le peuple français et sur ses attentats contre la liberté des nations, fait au nom du Comité de Salut public, Paris, 1793, p. 30 and 36. On Anglophobia during the Terror, Sophie WAHNICH and Marc BÉLISSA, "Les crimes des Anglais : trahir le droit," Annales historiques de la Révolution française, no. 300, 1995, p. 233-248.

100. "This accusation, by itself, is so ridiculous that it does not even deserve to be refuted. It would have been against England's own interests, moreover, to foment the revolt of the Blacks in Santo Domingo, since it should have expected, as indeed what followed confirmed, that those of their own islands would follow this example.": Herbert MARSH, La politique dévoilée..., op. cit., p. 28

101. For British public opinion concerning Leclerc's expedition, see David GEGGUS, "British Opinion and the Emergence of Haiti, 1791-1805," in James Walvin (ed.), Slavery and British Society, 1776-1846, London, Palgrave, 1986, p. 131-143.

102. [Marcus] RAINSFORD, A Memoir of the Transactions that took place in St. Domingo in the Spring of 1799, London, 1802, p. 17-18.

103. This assertion is in the second edition of the same work published under the following title: St. Domingo or an Historical, Political and Military Sketch of the Black Republic, London, 1802, p. 59-63.

104. David GEGGUS, "British Opinion...," art. cited, p. 137-138. 
105. Edinburgh Review, no. 1, 1802, p. 227.

106. Monthly Review, or Literary Journal Enlarged, no. 38, 1802, p. 332.

107. Critical Review, serie 2, no. 36, 1802, p. 348.

108. "Monsieur Dubroca, who was employed by the French government to slander poor Toussaint in a libel called his life, published at Paris while they were publishing rewards on his head at St. Domingo [...] Here I shall beg leave again to quote from the words of the Consul's champion Dubroca [...] That a defender of the Consul durst venture to speak of ambition as a crime is strange, but perhaps the only guilty ambition in Buonaparte's judgement is that which aims to promote the liberty and happiness of our countrymen.": see James STEPHEN, Buonaparte in the West Indies, or the History of Toussaint Louverture, the African Hero, London, J. Bretell, 1803, p. 5 and 13-14. It is worth mentioning that, in the following years, Stephen will go on to write Toussaint Louverture's biography: see James STEPHEN, The History of Toussaint Louverture, London, J. Butterworth and Son, 1814.

109. Grégory PIERROT, “'Our hero'. Toussaint Louverture in British Representations," Criticism, vol. 50, no. 4, 2008, p. 581-607.

110. Toussaint Louverture's frühere Geschichte nach Englischen Nachrichten bearbeitet, Fürth, 1802. With respect to the European fortunes of Toussaint Louverture, see namely David BELL, Men on Horseback..., op. cit., esp. p. 159-164.

111. "At present, the powers which compose the West Indian system, are only required to assist the strenuous efforts of the French government in the revolted islands, as they would be called upon in Europe to aid the regular government of France, were the Jacobins once more to spread themselves over the country, and to threaten an immediate restoration of the reign of terror,": Henry BRoUgham, An Inquiry into the Colonial Policy of the European Powers, Edinburgh, 1803, tome 2, p. 312-313.

112. "Such has been the history of the Negro population in St. Domingo, and such the steps by which the Slave Trade prepared the society in that unhappy island for all the miseries of a servile war. If nothing but a transient rebellion had been the consequence of that unnatural state of things which the rapid importation and cruel treatment of the Negroes brought about - if the French had been successful in their attempts to restore the dominion of civilised men in the revolted settlement-still the ineffable horrors of the fourteen years during which the contest raged, would have justified us in viewing with increased antipathy the African Slave Trade, the cause of so many wide spread calamities." Henry BRoUGHAM, A Concise Statement of the Question regarding the Abolition of the Slave Trade, London, J. Hatchard, 1804, p. 75.

113. James STEPHEN, The Opportunity, or Reasons for an Immediate Alliance with St. Domingo, London, J. Hatchard, 1804.

114. H. B. L. HUGHES, "British Policy towards Haiti, 1801-1805," Canadian historical Review, vol. 25, no. 4,1944, p. 402.

115. "Various reports of a massacre at this town and other places at a subsequent period, have been received from Jamaica and North America [...] I hope they will prove like a multitude of similar reports from the same quarters to be either wholly groundless, or great exaggerations of the truth; but considering the unparalleled circumstances by which popular rage and panic are likely to be excited, especially while the French still menace and annoy them from Cuba, such events are certainly not improbable." James STEPHEN, The Opportunity..., op. cit., p. 121-122.

116. Matt Clavin, "Race, Rebellion, and the Gothic: Inventing the Haitian Revolution," Early American Studies, vol. 5, no. 1, 2007, p. 1-29.

117. "It is pretended, that a justification is to be found for these blood-thirsty monsters in the treatment, which they so long endured from their masters. The same defense was set up for the Septembrisers of Paris [...] Indeed, the massacres of St. Domingo have been produced by doctrines such as those which produced the massacres of France, and in both instances the 
grounds of justification, or of palliation at least, were equally false. No monarchs were ever more mild than those of the House of Bourbon, and no masters were ever more merciful and kind than the planters of St. Domingo: it was, in both cases, the excess of lenity, or, perhaps, of indolence, in the governing powers, that first excited and afterwards encouraged and fostered the spirit of rebellion in the governed. And it is a shame to hear men, in this kingdom lamenting, or affecting to lament the hardships and privations of the negroes, when so many objects of real compassion amongst their fellow subjects seem to attract but a very little share of their attention... The negroes are a bloody-minded race: they are made and marked for servitude and subjection: it is the purpose which they were obviously intended for; and of this fact every day affords us fresh proof," Cobbett's Political Register, no. 6, 1804, July 28, p. 125.

118. Marcus RAINSFORD, An Historical Account of the Black Empire of Hayti: Comprehending a View of the Principal Transaction in the Revolution of Saint Domingo, with Its Ancient and Modern State, London, J. Cundee, 1805, citing the edition with an introduction by Paul Youngquist and Grégory Pierrot, Durham and London, 2013.

119. Ibid., p. 8.

120. See on this topic Marlene DAUT, Tropics of Haiti... op. cit., p. 56-61.

121. Marcus RAINSFORD, An Historical Account of the Black Empire of Hayti..., op. cit., p. 84-103 and 131.

\section{RÉSUMÉS}

Jean-François Dubroca, polygraphe actif pendant les années napoléoniennes, ne nous apparaît aujourd'hui que comme ayant rédigé les premières biographies, aux traits d'ailleurs lourdement racistes, de Toussaint Louverture (1802) et de Jean-Jacques Dessalines (1804). Cela pourrait étonner, car, tout au long des années précédentes, Dubroca avait été un révolutionnaire acharné : en 1792, à la chute de la monarchie, il se défroqua et se rangea du côté des républicains ; pendant la Terreur il était proche des déchristianisateurs ; après Thermidor, il fut parmi les promoteurs $\mathrm{du}$ culte théophilanthropique; et, à la veille de Brumaire, il faisait partie du Portique Républicain, un cercle d'écrivains démocrates. Les biographies de Louverture et de Dessalines représentent donc un sombre exemple de l'involution de la culture politique républicaine dans les années du Consulat. Cet article procède par conséquent à une lecture des travaux de Dubroca parus au début du XIX ${ }^{\mathrm{e}}$ siècle - parmi lesquels on trouve une des premières biographies de Bonaparte et un rapport sur l'importance du retour de la Louisiane à la France - pour éclairer les conditions et les motivations qui facilitèrent un tel dérapage. Il est hors de doute que son soutien à la politique américaine de Bonaparte lui imposait la dénonciation de l'immoralité des anglais, ouvertement accusés d'inciter les noirs de Saint-Domingue pour profiter des richesses de l'île. Il s'agissait d'une polémique qui annonçait le début de la guerre de civilisation. La victorieuse résistance opposée par les noirs aux troupes françaises fit le reste et poussa Dubroca à dénaturer l'œuvre civilisatrice de la révolution en une attitude coercitive face à ceux qui la refusaient. Sur cet aspect reposent toutes les conditions pour la naissance du nouveau colonialisme.

Jean-François Dubroca, polygrapher during the Napoleonic years, is only known to us today as the author of the first biographies, featuring heavily racist traits, of Toussaint Louverture (1802) and Jean-Jacques Dessalines (1804). This might come as a surprise as, throughout his previous years, Dubroca had been a relentless revolutionary: in 1792, when the monarchy fell, he defrocked and sided with the Republicans; during the Terror he was close to the 
dechristianisation; after Thermidor, he was among the promoters of the theophilanthropic cult; and, on the eve of Brumaire, he was part of the Portique Républicain, a circle of democratic writers. His biographies of Louverture and Dessalines thus represent a dark example of the involution of republican political culture in the years of the Consulate. This article therefore examines the works of Dubroca during the very first years of the 19th century-among which we find one of the first biographies of Bonaparte and a report on the importance of the return of Louisiana to French rule-and aims to shed light on the conditions and motivations that facilitated such a dérapage. There is no doubt that his support for the American policy of Bonaparte forced him to denounce the immorality of the English, openly accused of inciting the slaves of Santo Domingo as a strategy to take advantage of the wealth of the island. It was an attack that would announce the beginnings of a war of civilisation. The victorious resistance of the blacks against the French troops pushed Dubroca to disfigure the civilising work of the revolution into a coercive attitude meant for those who refused it. The path for a new colonialism had been laid.

\section{INDEX}

Keywords : Jean-François Dubroca, Saint-Domingue, Political propaganda, Civilising mission, Colonialism, Propagandist, Consulate, Racism

Mots-clés : Jean-François Dubroca, Saint-Domingue, Propagande politique, Mission civilisatrice, Colonialisme, Propagandiste, Consulat, Racisme

\section{AUTEUR}

\section{ANTONIO DE FRANCESCO}

Dipartimento di Studi Storici

Università degli studi di Milano 